\title{
An Analysis of the Teaching Reform of "Five - Level Synchronization" of Ideological and Political Theory Courses in Colleges
}

\author{
Kui Lan \\ Marxism School of Sichuan University of Arts and Sciences, Dazhou Sichuan, 635000, China
}

Keywords: College, Ideological and Political Theory Courses, Teaching methods, Reform

\begin{abstract}
Since the "05"program carries out; the reform of ideological and political theory courses in colleges and universities has been worked, and achieved a good result. However, there are still some problems in the combination of theory and practice, the effectiveness of teaching, the construction of teaching staff and assessment. To enhance the pertinence of ideological and political education, improve the teaching effectiveness and appeal of ideological and political theory course, integrating theory with practice, sharing high quality teaching resources, updating teaching content, innovating teaching methods, integrating the internal and external teachers, constructing the evaluation model of diversification are effective, the five lines work along in teaching reform make the combination of theory and practice, teaching resources, teaching content and thematic information of teachers, evaluation of diversification all work .
\end{abstract}

\section{Introduction}

In the December of 2016, Xi Jinping at The Meeting of the national Ideological and political work conference stressed: "The Ideological and political theory course will continue to strengthen in the college and universities, enhance the affinity and targeted to meet the growth and development needs of our students, ...... and enhance the sense of the times and appeal." [1] It points out the direction for the reform and innovation of the Ideological and political theory course and provides theoretical and practical guidance. According to the need of curriculum reform of Ideological and political theory course, only finding the way to solve these practical problems, which can insist on truth and do practical work, innovative teaching methods, strengthen the teaching of attractive, persuasive and appealing, with practical teaching, to win student's love.

\section{Adhere to the combination of theory and practice and realize the integration of theory and practice}

Through a variety of forms, the theory and practice of the depth of integration, so that students in practice to deepen the understanding of theoretical knowledge and insights broaden their horizons and enhance the ideological realm." [2]

First, in the "Mao Zedong Thought and the theoretical system of socialism with Chinese characteristics," "Introduction to the basic principles of Marxism," "ideological and moral cultivation and legal basis" three ideological and political theory courses in the implementation of the " $2+1$ " teaching reform. " $2+1$ " teaching reform, that is, in the total credits, the total class to maintain the same premise, the original 3 hours / week of the theoretical class, with "2 hours in week of the theoretical class and 1 hours in week Practice class ", the practice class content in strict accordance with the" ideological and political theory course practice teaching rules "requirements, students in the second class and spare time to complete. In order to protect the practice class is not discounted, do not go through the field, do not take the form, the teaching and research section has carefully developed three practice teaching practice details, so that the implementation of the practice class early implementation plan, semester examination and acceptance, the end of the school assessment, practice as Process assessment, together with the usual results together into the end of the total score 
of students. "2 +1 " teaching reform further highlights the student subject, teacher-led, so that students actively participate in the teaching practice, in practice to enhance sentiment, the use of theoretical knowledge to solve practical problems, but also through practice to sum up experience, the formation of theory, to promote the integration of theoretical practice.

Second, relying on the regional advantages of Sichuan and Shaanxi Soviet region, mining local red resources, the school is planning to build "one room five museum a garden" publicity and education teaching platform, that is, Sichuan-Shaanxi Soviet Red Resources Scenario Simulation Laboratory, Sichuan, Shaanxi and Shaanxi Red Resources Library, The Sichuan-Shaanxi Soviet area red painting and calligraphy exhibition hall, the Sichuan-Shaanxi Soviet area red folk art exhibition hall, the Sichuan-Shaanxi Soviet red character memorial hall, the Sichuan-Shaanxi Soviet area online red exhibition hall, the Red Army Park, also with the former residence of Zhang Aiping Memorial Park, Signed a cooperation agreement, sharing the red teaching resources, and gradually the red resources into the ideological and political education practice teaching results, to facilitate students in the practice of teaching to complete the experiential practice.

Third, the project funding for college students' ideological and political education social practice topics, through research to enhance student theory and practice the ability to integrate. For the project to clear the guidance of teachers, practice "tutor system", the teacher guides the whole student research, to help students choose a good question, do the argument, collect information, write the task report. A school from 2012 to date has funded more than 100 projects, some of the results of the provincial and municipal level awards.

\section{Build and share high quality resources, to achieve teaching resources information}

"Internet +" background, "the global knowledge resource library has been formed, the quality of education and teaching resources more and more enriched, teachers and students to make full use of the Internet to provide a huge information resources to fully explore the different areas, different areas of hot and difficult issues, Enrich the perspective of the problem of analysis, expand students' learning horizons.

First, the establishment of a red education website. The school has established a red education website, which links the Central Literature Research Office, the Communist Party of China Historical Network, the Central Revolutionary Base History Museum, Zhu De comrades residence Memorial Hall, Deng Xiaoping Memorial Hall, Jinggangshan Revolution Museum, Sichuan-Shaanxi Soviet Red Pavilion, ideological and political theory Course sites and other red education website, easy to teachers and students online browsing, online learning.

Second, the establishment of the ideological and political education We Chat public number, regularly updated updates the latest political hot spots, the national policy, students learn experience. School counselors to establish a counselor We Chat public and live broadcast platform, timely sharing of students' ideological dynamics, and timely response to student demands. "Xi Xin listen to the text" public number is a counselor of our school to establish a share of creative sentiment sharing platform, the previous graduates in school, life and post-graduate thinking sent through the We Chat public number to share students, for example, a " Learn slag, "the inverse caused a lot of students in the resonance.

Third, is planning the construction of the ideological and political theory of cloud teaching platform. Through the perfect process control technology and human-computer interaction mode, to ensure that students fully exposed to each knowledge point, and through the massive question bank, to strengthen students' memory of knowledge points. Online check, bbs, notice, micro logging, private letter and other tools to achieve synchronization, asynchronous, one to many, one to one more rich communication model for teaching to expand the larger space. The next step, the school will choose an ideological and political theory course as a lesson teaching, in the school to implement ideological and political theory class teaching. 


\section{Teaching system to achieve the teaching content of the thematic}

"Many experiences have proved that the ideological and political theory courses in colleges and universities want to attract students and have a lifetime impact on students, and they can not be a general lecture, especially if they can not," said Chen Zhanan, a professor and chief expert at the School of Marxism in Peking University. Teaching materials, but should be another path: for students to carefully design and carefully set up a high level of lectures to achieve neither left the teaching materials, and not copy the effect of teaching materials. "To achieve the teaching system into a teaching system, condensed into a topic Form, is the teaching content of the topic of exploration.

First, the "situation and policy" to implement the thematic teaching. In view of the policy, change and timeliness of the situation policy curriculum, the topic teaching mode of the situation and policy course is constructed. Better solve the situation and policy courses as the only ideological and political theory of teaching materials, the collection of data collection cumbersome, long lesson preparation time, teaching requirements, the assessment is more difficult, and the face of complex situation changes and Student characteristics, and a series of questions. "The situation and policy" every semester according to the Ministry of Education teaching points, combined with the world situation, national conditions, provincial and municipal school situation, through the collective lesson preparation, concise teaching topics, so that teaching and political integration, combined with the latest ideological and political research. "Situation and policy" special teaching practice 10 years, in the development of innovation and change, has become a school of ideological and political theory of the highlights and characteristics of teaching.

Second, the thematic teaching, in the teaching will not be revised because of the lag in the teaching and feel at ease, according to the development of social affairs, in time to add the latest content to the teaching. Teachers will be concerned about the hot topic of political affairs, the first time the country's major policy and policy will teach the general secretary of the important speech to the spirit of teaching, to update and improve the teaching content, so that teaching content with the times.

\section{Strengthen the integration of teachers, teachers to achieve diversification}

The characteristics of the application of colleges and universities and the needs of personnel training determine the importance of the diversification and collaborative innovation of teachers. The use of part-time teachers is a common practice for all types of universities in the United States. According to statistics, "1970 part-time teachers accounted for $22 \%$ of the total number of teachers, part-time teachers in 1989 , the proportion was $36.4 \%$, by 1999 , the proportion of US college part-time teachers has reached $43 \%$, part of the community college part-time teachers to 60 More than "." [3] To employ part-time teachers is not only "to make up for the lack of the number of faculty, but complementary advantages, improve quality, aim at development." [4] To further integrate the two resources outside the school, to achieve the ideological and political theory class "Multi-division ".

First, the school to achieve the "interdisciplinary big linkage", school philosophy, political science, sociology, history, law, education, economics and other disciplines of the subtropical high titles, was appointed ideological and political theory part-time teachers, Integrated in the party work and trade unions, Communist Youth League, school team, and fully tap the party team's respective advantages.

Second, from the local party committees, governments, research institutes, the party school, the relevant departments of the relevant cadres, entrepreneurs selected a number of part-time visiting professor, so that they become a member of the ideological and political education team, Into the ideological and political theory class.

\section{Build a variety of assessment and evaluation model, to achieve diversification of assessment and evaluation}

First, the examination content to take "classroom practice assessment + professional theoretical knowledge assessment" module combination of assessment methods. Specifically, for the basic 
theoretical knowledge, continue to follow the traditional examination methods, through the closed form of students to examine the basic theoretical knowledge of learning, understanding and mastery. Practice class examination, and then write research reports or small papers in the form of examination. In the practice of teaching, to take the group teaching way, the class will be divided into a number of groups, according to the group members, teachers for the group design "menu" program, students free combination, cooperation completed. In practice, the members of the group wrote a large number of reading, research reports, papers, etc., also actively participated in volunteer service activities. In the teaching period and the end of the inspection stage, the group through the PPT to the class show, sharing the exchange of practical results. The teachers randomly selected two "public judges" (students) together to form a temporary practice class examination group, the results of the activities of the group show the results of the assessment, scoring, the students completed the research report, the paper to review, to complete the practice of examination.

Second, the form of examination using "paper quality examination + on the machine test" combination of assessment form. The examination of the use of writing papers, survey reports of paper assessment form, the final exam on the use of centralized examination, the implementation of "teaching separation", "a multi-test", Sichuan University of Arts and ideological and political theory on the machine examination from 2014 onwards , Including the establishment of test questions, the design of the examination system, after more than 2 years of full preparation, after repeated pilot, in the 2016 school ideological and political theory of the end of the exam to achieve more than 7,000 people on the machine examination, significant savings in paper, Saving the labor force, saving money, practicing the "green development" concept, by teachers and students praise.

Third, we will explore the "works" assessment mode in the disciplines of science and engineering, chemical industry, construction, tourism management, finance and management, art and so on, and cultivate students' awareness of innovation and entrepreneurship and enhance the ability of applied technology. Encourage students to complete the music works, painting and calligraphy works, design models, planning programs, invention patents as a normal assessment of important content, the ideological and political theory and professional construction of collaborative interaction, to achieve ideological and political theory with the same class of students to form a synergistic effect.

\section{Conclusions}

The ideological and political theory course "five simultaneous" reform in the improvement of the ideological and political theory to strengthen the course, to further deepen the ideological and political theory of education and teaching reform, and constantly improve the ideological and political education targeted, and enhance the effectiveness of education and teaching.

\section{References}

[1] http://www.moe.edu.cn/jyb_xwfb/s6052/moe_838/201612/t20161208_291306.html.

[2] Pan Xueliang. Reflections on the Whole Process of "Four Self - confidence" Education Running through Ideological and Political Theory Course in Colleges and Universities, Leading Journal of Ideological \& Theoretical Education. 2016, (10):104-107.

[3] Shao Ximei. Opportunities and Challenges Faced by Ideological and Political Theory Courses in Colleges and Universities under the Background of Internet, Journal of Shandong Academy of Governance. 2016, (6):115-118+122.

[4] Sheng Yunlong. The System Guarantee of Teachers' Quality in Foreign Universities, Research on teachers in Chinese Universities. 2004, (4):24-28.

[5] Li Ying. Reflections on the Construction of Teaching Staff in Colleges and Universities, Journal of Nanjing University of Science and Technology (Social Sciences Edition). 2004, (2):79-82. 